\title{
Theology and psychology \\ - the interdisciplinary work of Fraser Watts
}

\author{
Willem J Smith (Benoni) ${ }^{*}$ \\ Research Associate: Department of Practical Theology \\ University of Pretoria
}

\begin{abstract}
In the preface to his book, Theology and Psychology, Fraser Watts, a lecturer in Theology and Natural Science at the University of Cambridge, states that he approaches "... the interface between theology and psychology by looking at each discipline from the perspective of the other. This includes a religious perspective on several current hot topics in psychology, such as evolution, neuroscience, and computer intelligence. I also consider theological topics like divine action, salvation history and eschatology, in each case using the psychological perspective in a different way". By taking an interdisciplinary approach, Watts aims at proposing a psychology of religious experience. He considers theology to be the rational reflection on the Christian tradition. When exponents of this tradition are in dialogue with exponents of psychology, the focus falls on human nature. Watts admits that a certain lack of competence in one of the two disciplines can be a problem when working in an interdisciplinary way. However, he is willing to take the risk. Watts worked in psychology for 25 years and was also involved with a medical research council, before taking up a position at the Faculty of Divinity, University of Cambridge.
\end{abstract}

\section{INTRODUCTION}

Fraser Watts, Starbridge lecturer in Theology and Natural Science at the University of Cambridge (UK), is known for works such as Christians and bioethics (SPCK), Science meets faith (SPCK), Psychology for Christian ministry (Routledge) and The psychology for religious knowing (CUP). In his latest work, Theology and psychology (Ashgate: 2002), he examines both the

\footnotetext{
"Review Article: Watts, F 2002. Theology and psychology. Burlington, VT: Ashgate. Dr Willem $\mathrm{J}$ Smith (MA, PhD) is a research associate for the project "Theories of Practical Theology and Philosophical Hermeneutics", directed by Prof Dr Yolanda Dreyer, Department of Practical Theology, University of Pretoria.
} 


\section{Theology and psychology}

disciplines of psychology and natural science, one from the perspective of the other.

Watts departs from the psychology of the nineteenth century, which was often hostile to religion. He seeks a psychological position which is as neutral as possible. Using data obtained from a survey, the book attempts to provide information about the kinds of people who are religious, where religious experience happens, where conversion takes place, who attends church, how children learn about religion and what causes stress for ministers. The data from this survey could potentially be of value for planning the ministry and mission of the church. The interface between theology and psychology could offer great support when applying psychological perspectives to the pastoral work of the church. Watts $(2002: 2)$ claims that Oscar Pfister, a Lutheran pastor and a friend of Freud, was the first to recognise the meaning that psychology could have for the pastoral work of the church. Between World Wars I and II, the Methodist minister Leslie Weatherhead was a key figure in Christian Pastoral Psychology in the United Kingdom. In the post-war era, Frank Lake's (1966) Clinical Theology became a landmark in the integration of psychiatry, psychotherapy and theology. In recent years, extremes found in Christian attitudes to pastoral psychology range from suspicion or even hostility to an uncritical enthusiasm which apparently assumes psychotherapy to be the Christian gospel itself! To set Christian leaders as well as psychologists at their ease, Watts (2002:3) states clearly that the purpose of his book is not to pursue either the psychology of religion, or pastoral care, nor does he consider the theologies of non-Christian faith communities. He is not concerned with the practical life and work of Christian communities.

\section{THE NATURE OF THE DIALOGUE}

Watts (2002:7) asks: "[W]hat kind of relationship should there be between theology and psychology?" Should it be a relationship in which one discipline assumes authority over the other, should one of the disciplines be assimilated by the other or are they incompatible and require revision in order to bring them into a harmonious relationship? Watts does not see any radical incompatibility between the two disciplines. Sometimes there are parallel debates in the two disciplines and there is scope for constructive mutual influence. However, an important question is: "How far should such a dialogue go?" (Watts 2002:8). Should the two disciplines be moved beyond dialogue to a point of integration? Should both disciplines be allowed to lose their distinct identities? This could only happen if there were some kind of superiority and subordination between the disciplines. A constructive dialogue could only mean there would be a fruitful future for both disciplines. 


\section{THE DIVERSITY OF THE DISCIPLINES}

While engaged in the dialogue between these two disciplines, one should never forget that they are divergent. Psychology has a hierarchical structure, based on detailed research findings, on which theories are constructed. Psychology also involves a variety of different approaches, including biological psychology, social psychology, clinical psychology and behaviourism.

The tradition of Christian theology is also rich in its variety. There is no single theological position, especially for instance when discussing issues such as the nature of the human soul, free will in Christian theology, and the doctrine of predestination. In his conclusion of the argument on the diversity of the two disciplines, Watts (2002:11) holds the view that "[h]ow you coordinate theology and psychology depends on the part of the Christian tradition with which you are mainly concerned."

\section{THE SCOPE OF THE CURRENT DIALOGUE}

Watts (2002:13) asserts that the current dialogue between theology and psychology focuses on four key areas:

- $\quad$ The first key area concerns general issues of human nature (evolutionary psychology, brain processes, learning and development, cognition and consciousness), which Watts discusses in Chapters 2-5.

- The second key area of religious experience and the nature of human religiousness are discussed in Chapters 6-7.

- $\quad$ The third key area is allowing theology to set the agenda as far as matters of systematic theology are concerned, while inviting psychology to contribute. This discussion spans Chapters 8-10.

- $\quad$ The fourth key area concerns theological and psychological perspectives on Christian pastoral care. However, Watts does not take the specialist area of pastoral care into consideration or discuss it in detail.

In Chapter 11, the final chapter, Watts discusses what is called "metatheology". He develops a psychological perspective on the process of doing theology, focusing on the tendency of theology to function in terms of dichotomies. Watts (2002:15) believes that if the dialogue between theology 
and psychology encourages others to take part in and extend it, this book "will have done its job".

\section{THE FIRST KEY AREA: GENERAL ISSUES OF HUMAN NATURE}

Paragraphs 5.1 to 5.3 of this article consider the three main reductionist approaches to human nature. Paragraph 5.4 discusses the general issues in Christian and psychological approaches to human nature.

\subsection{Evolution}

Concerning evolution. the dialogue between theology and psychology is interested in the evolutionary approach to human nature and the influence of evolutionary theory on Christian faith. The evolutionary approach to human beings has been pushed into two directions. First, from the mid-1970s, there was an approach to social behaviour, known as sociobiology. Second, there was a movement in the human sciences in the 1990s, called evolutionary psychology.

\subsubsection{Sociobiology}

Sociobiology has been very successful in studying animal and human social behaviour. However, there are so many discontinuities between animal and human unselfishness (altruism), that it is impossible to generalise the conclusions drawn from animal and human social behaviour. Watt takes a strongly critical stance toward human sociobiology. Moreover, sociobiologists also adopt widely differing positions, and there is no scientific basis for settling these differences. Scientific writing on sociobiology is often inexact and potentially misleading. Perhaps that is why psychologists and social scientists have not taken the public debate about sociobiology seriously.

\subsubsection{Evolutionary psychology}

In contrast to sociobiology, evolutionary psychology is an internal revolution in psychology and social science, which is determined to completely change the face of the human sciences. Evolutionary psychologists want to make the following main contributions. Firstly, they have a quest to understand how human traits and attributes might have arisen through natural selection. Secondly, they are concerned with how far human capacities such as language, are innate. Thirdly, they want to determine the strength of human capacities in people's experience of emotions and in their acts. Watts (2002:20) believes that this revolution within evolutionary psychology should 
soon settle down and may make a major contribution to our understanding of human nature.

\subsubsection{Evolution and God}

Can evolution be compatible with the Christian doctrine of creation? Some scientists, such as Charles Kingsley, hold the view that it is easier to believe that God created primal forms capable of development, than that God created every species already fully developed. By contrast, Jacques Monod (1972) rejects these assumptions. He claims that evolution was pure, blind chance and as such is inconsistent with the assumption of a purposeful Creator. Dawkins (1986) has a more moderate view. He regards evolution as reflecting a "tamed chance" (Watts 2002:28).

It is necessary to distinguish between the stronger and the more moderate versions of the idea of evolutionary progress. The strong version claims that there has been consistent, linear evolutionary progress. However, Watts (2002:30) supports the more moderate version. He does not agree that evolution has progressed along fixed lines, but one can at least assume God's intention and purpose that, through evolution, creatures capable of relating to God, would emerge.

Watts (2002:31) cites Ruse (2001) when asking: "Can a Darwinian be a Christian? Absolutely! Is it easy for a Darwinian to be a Christian? No ...". He regards the evolutionary approach to human nature as interesting and helpful, but notes that is not the only approach with validity. From a theological and also from a psychological point of view, evolution can be seen as a complementary perspective on human nature.

\subsection{Consciousness, brain and God}

\subsubsection{Consciousness}

The topic of consciousness is currently the focus of multidisciplinary interest. However, consciousness remains a mystery which scientists find difficult to deal with. Watts (2002:34) takes an overview of existing research. He focuses especially the theological reasons for being interested in consciousness, which is that the "... conscious awareness of the presence of God, plays an important role in religious life". Believers often see God as the centre of consciousness. One could agree with Watts' view that, though consciousness is located in the brain, there is reason to think that we currently have too restricted a view of the extent to which mental powers are physically localised in the brain. Consciousness goes beyond the physical organs of the body. 


\subsubsection{God and consciousness}

What can be said about God and the human mind? Watts (2002:42) states that God is the exception: God's "mind" is located in a physical brain. God is not dependent on a body in the same way as a human mind. A dualist view of the mind links human beings to the mind of God. Another important development the study of the human mind is the emphasis on how closely intertwined the passive and active mental processes are. In this regard, philosophers such as Gadamer see the mind as actively creating meaning from a frame of reference of understanding.

\subsubsection{Immortality}

Immortality is often regarded as the continued existence of some kind of essence or consciousness after the death of the body. Immortality is sometimes seen in terms of a disembodied soul. The Christian tradition struggles with three views of immortality. The first idea is based on the dualistic view of human nature. The second idea, that the soul can continue to exist without body or brain, strains scientific credibility. The third idea, namely the dualistic approach to immortality, claims that the soul survives death but cannot give a satisfactory account of how this survival is achieved. According to Watts (2002:46) there is growing interest in the resurrection of the body, also because the Apostles' Creed focuses on the resurrection of the body, rather than the survival of a disembodied soul.

\subsection{Computer (artificial) intelligence}

Artificial Intelligence (Al) is generally in conflict with religious views. In recent decades there has been a tremendous development in Al. Computers now have the capacity to improve their performance through learning and experience. This, for example, was applied to a field such as speech recognition where a computer is programmed to recognise speech and it becomes more accurate as it gains experience of a particular user's speech.

\subsubsection{Computer simulation of human intelligence}

Computers have lately become an aid to understanding the functioning of the human mind. This field is known as computer simulation, rather than artificial intelligence. Two presumptions are made regarding Al: firstly, it should be possible for all aspects of human intelligence to be captured in computer form and secondly, the human mind works like a computer programme. These claims are often designated as "strong Al" (Watts 2002:50). On this point, we 
should argue that computers could never achieve consciousness, despite their facility to simulate all kinds of intelligent activity.

\subsubsection{Computers and consciousness}

Computers cannot easily simulate human consciousness, since consciousness is a sensory experience. Consequently it is not possible to programme a computer to simulate consciousness, in the sense of having a subjective "feel" for something. Remembering something means reconstructing it, not just bringing it into the spotlight of consciousness. That is why human memory differs so widely from computer memory. Although it is not currently possible to program computers to respond emotionally, Watts (2002:53) asserts that this is one of the key challenges in computer research today.

\subsubsection{Theology and Al}

Creating computers that would act like human beings would, in a sense, be "playing God". Creating an artificial construct which would function in the same way as the human mind, body and soul, would be to place human beings in God's role as creator. Al scientists face different problems when creating humanoid computers, such as how to create the kind of free life that human beings have and how to prevent computers from becoming monstrous or self-proliferating and destructive to humans.

What God did, was to "grow" life, rather than to manufacture it according to some pre-specified plan. I very much doubt whether the human freedom of life and freedom of choice can be programmed into computers. Every form of consciousness created by humans will always be artificial or Al. Will it ever be possible to create computers that could represent our Christian beliefs, or play their part in building up the body of Christ?

\subsection{Persons, souls and selves}

\subsubsection{Christian and psychological approaches to human nature}

After discussing the three main reductionist approaches to human nature the focus next moves to general issues in Christian and psychological approaches to human nature. Psychology is both a biological and social science. It consists of a family of disciplines, rather than a single discipline, and covers a broad spectrum of approaches. That is why there will always be tension of some kind between the two main constituting disciplines of biology and social science. Part of the difficulty with integrating the biological and social aspects of the study of human beings in psychology is that psychology is not only a 


\section{Theology and psychology}

natural science dealing with the biological aspects of human beings but also a social science dealing with the relational aspects of being human. Psychology is placed on the dividing line between the natural and social sciences, which often creates a dilemma for the discipline.

The relationship between science and theology would be greatly aided by a view which would reconcile the social and the biological aspects. One should bear in mind that science and theology have contrasting approaches to human nature. One of the main differences between the scientific and theological approaches is that science often emphasises biological aspects, whereas theology generally ignores them. By contrast, theology often emphasises the moral aspects which tend to be neglected by psychology. Watts (2002:69) states that there is currently a movement in science and theology to minimise these differences.

\subsubsection{Soul and self}

Christian thinking about the soul has often been dualistic, conceiving of the soul as a potentially disembodied entity. If consciousness is inseparable from the physical brain, perhaps the soul should be regarded as inseparable too. At times the soul has been regarded as an immaterial entity created by God before a person's natural birth, but this view is by no means universally accepted. From a psychological point of view, the soul is best seen as a qualitative aspect of the person. The soul is understood as a perspective, rather than as an entity. Watts (2002:72) points out some ways in which the soul is not parallel to the mind. Consciousness is a universal property of human beings, but it remains a question whether the soul is universal in the same sense. Every human being has at least a capacity for the life of the soul.

\section{THE SECOND KEY AREA: RELIGIOUS EXPERIENCE AND HUMAN RELIGIOUSNESS}

Up to this point the focus has been on the central aspects of human nature. The current dialogue between theology and psychology also focuses on a second key area, known as the psychology of religion, that focuses on religious experience and the nature of human religiousness. Watts (2002:77) considers both "religious" and "mystical" experience, though he does not contrast the two concepts too sharply. He emphasises that the phenomenological, neurological and socio-psychological approaches in psychology go hand in hand, and that it would be good practice to consider the relevance of each of these non-theological approaches. 


\subsection{Religious experience: cognitive neuroscience}

\subsubsection{Reductionism and religious experience}

There are three main reductionist critiques of religious experience in psychology. The first, stemming from Freud, sees religious experience as a reflection of personal needs. The Freudians suggest that people believe in a good and powerful God, because they have a psychological need to do so. The second critique is that a psychoanalytic approach to religious experience is be as reductionist as Freud himself was. The social constructionist critique is currently the third and probably the most vigorous reductionist critique of religious experience, and emphasises that religious experience is shaped by its social, cultural and linguistic context.

\subsubsection{Towards a multilevel cognitive theory}

Watts (2002:85) states that by cognitive, he means the structures and processes that shape attention and memory, mediate our responses to experience and are the basis for our understanding of the world. Watts notes that the first generation of cognitive theories of emotion was single-level theories. The first multilevel cognitive theory of emotion distinguishes three basic levels, namely sensory-motor, conceptual and schematic. Watts (2002:88) regards this theory as neutral as far as the reality of religious belief is concerned. A theory based on religious consciousness may make religion seem to be nothing more than a side-effect of the way our system functions.

\subsection{Religious experience: Interpretation and social context}

Having discussed the cognitive neuroscience perspectives on religious experience, Watts (2002:89) now focuses on issues concerning the social construction of religious experience.

\subsubsection{Social constructionism}

Social constructionists tend to define religious experience in terms of the distinct content of experience. Concerning the question as to how religious experience is shaped, social constructionists emphasise that different faith traditions give rise to different patterns of religious experience. It should be borne in mind that classical historical texts do not constrain the study of religious or mystical experience. There are other methods of studying mysticism besides the study of the classical mystical and traditional texts, such as the empirical research methods of the modern human sciences. 


\subsubsection{Theoretical psychology}

The debate on theoretical psychology involves the role of interpretation in religious experience. Experience is never raw or uninterpreted. Experience is cognitively constructed. What cognitive psychologists call construction in the interpretation process, is similar to what philosophers call interpretation. The information we gather is not "neutral view from nowhere information" (Watts 2002:95). It is selected and processed according to the kind of environment that we have experienced previously and is coloured by our memories.

Information is not always processed fully and all at once. People continue to process the information they have gathered. Watts (2002:95) recalls that Schleiermacher (1768-1834), the father of modern theology, was the one who linked religion with emotion by stating that feelings are the basis from which religious experience arises. The aim here is not to pit religious experience as an act of human interpretation against theological accounts which see it as a gift of God. We should rather combine a theological discourse - being aware of the presence of God - and a more natural discourse about the way religious experience arises from the human work of interpretation. There is no reason for restricting oneself to only one of the two discourses about religious consciousness.

\section{THE THIRD KEY AREA: MATTERS OF SYSTEMATIC THEOLOGY}

The third key area in the dialogue between theology and psychology, namely systematic theology, investigates the implications for revelation and divine action. Specific topics in systematic theology will now be viewed from a psychological perspective.

\subsection{Divine action and human experience}

\subsubsection{Providence and persons}

Theology requires that God should have some scope to act in relation to specific acts in the world. Some of the key events seen by Christians in terms of divine providence relate to the unique figure of Jesus Christ, while others relate to ordinary human beings. The focus therefore is not on God's action in the natural world, but on God's action in relation to humanity. It is assumed that people's thoughts can become attuned to God, that people can open themselves to God's influence and that they can, in some measure, discern God's will. The question is how these assumptions accord with the scientific study of the mind and brain. 


\subsubsection{Mind, brain and divine action}

God's influence on people should be regarded holistically. Therefore God's relationship with human beings should not be seen as purely spiritual. When God acts in relation to people or reveals God-self to them, this is reflected in all levels of personhood, including brain processes, cognitive processes, phenomenal experience and observable behaviour.

\subsubsection{Moral and religious intuitions}

Conscience relates both to thoughts and actions, and the two are intertwined. Discerning what is the right thing to do seems to be an enacting kind of knowing. This is the tradition that views conscience as the inner voice of God. Granted that all religious experiences and all other intuitions of conscience are contextualised, the question still remains whether there might not also be some direct influence from God on religious experiences and moral intuitions. Thoughts and intuitions may arise entirely through the ordinary processes of social influence, but nevertheless be in accordance with the mind and purpose of God. The belief that the Spirit can dwell within people as a source of revelation and guidance is an important part of the Christian tradition.

\subsection{The Fall, Christ and the evolution of consciousness}

The theory of evolution propounded by Darwin has always evoked divergent religious reactions. The integration of theology and evolution has taken a variety of forms. On the one hand, some people sought to link the evolution of species with a general doctrine of moral and spiritual progress. On the other hand, others took natural selection more seriously, particularly those who espoused the Calvinist belief in predestination. One of the most difficult theological challenges posed by the theory of evolution was to find a way of reconciling the extinction of many species with the creative purposes of God.

Watts (2002:113) points out that Rahner, a Catholic theologian (1978), showed that there was no incompatibility between theology and evolution. Rahner wished to co-ordinate the two approaches in a way that illuminated both. His assumption was that the scientific and theological approaches would remain separate and provide distinctive and complementary perspectives. Watts' focus here is on the relation between evolution and the Christian story of salvation history; the story of the fall of humanity and the restoration of humanity's relationship to God through Christ. He discusses the whole process of the evolution of human consciousness, as well as the fall of mankind as a key topic in Christian doctrine and various attempts to defend it. Focusing on the fall of mankind from a psychological point of view, Watts 


\section{Theology and psychology}

mentions the opinions of various leading psychologists, such as Jung and Steiner.

Having considered how the fall relates to the evolution of consciousness, Watts (2002:123) places the whole story of Christian salvation history in this context by asking how Christ relates to evolution. Once again Watts' opinion is informed by Rahner's insights. The fall not only affected human beings, but all of creation too. Creation was subjected to futility, but will be set free from its bondage to decay (see Rom 8; 1 Cor 15:42-44).

In my opinion, Watts' insights (2002:131) can be supported, namely that the direction of consciousness has changed in its relevance to the salvation of nature. It is no longer about the spiritual communicating with humanity through nature, but rather about the spirit within humanity guiding the perception of nature. The only way to avoid seeing nature as simply ripe for exploitation, would be for the imagination guided by the spirit to perceive nature as a precious and valuable gift. The redemption of nature may need to be mediated through human consciousness, even if ultimately the capacity to do so is one of the fruits of the spirit.

\subsection{Eschatology: Subjective and objective aspects}

Watts' purpose (2002:133) here is to examine Christian eschatology, the theology of God's purposes for the future, in the context of the interdisciplinary dialogue between theology and the sciences.

\subsubsection{Eschatology and natural science}

The natural sciences make predictions about the future of the universe. They predict that it is descending into disorder. The world of Christian eschatology is completely different from the impersonal predictions of cosmology.

Eschatology is essentially moral. It is about a good future, the Christian future promised to human beings by a loving and faithful God. Christian eschatology functions in a world vastly different from scientific predictions about the future of the universe. Popular scientific writing about the future of the universe, predicting for example that it will end in a big crunch or in death by heat, appears to be propositional. Eschatology without God does not make much sense. Christian eschatology maintains a careful balance, saying neither that we are helpless victims of fate, nor that we are masters of our future. That sense of balance is lacking in scientific eschatology.

\subsubsection{Eschatology and psychology}

In eschatological hope, there is a distinctive relationship between the here and now and the hoped-for. The Kingdom of God is inaugurated, it is already here 
as well as not yet here. Watts $(2002: 136)$ claims that this is also psychologically important. Hope requires a sense of continuing inauguration. There is nothing left to hope for in a fully realised eschatology. Hope has to maintain a clear link between the foreseeable future and the ideal future. Only if this connection is maintained in human consciousness, can the actual future take on some of the characteristics of the hoped-for future.

\subsubsection{Resurrection}

Eschatology also entails Christian beliefs about resurrection. The resurrection of Christ can be discussed in a dialogue with either the natural or the human sciences. It is the idea of the resurrection of a body in which the natural sciences would take most interest. One question concerns the possibility of physical resurrection, where many would be inclined to reject this as a scientific impossibility. However, the sciences have always been careful about stating that events are scientifically impossible. When examining resurrection in a dialogue with the natural sciences, the objectivity of the event appears to be overemphasised. By contrast, when examining resurrection in connection with the human sciences, the subjectivity of the event seems to be overemphasised in a way that leads all too easily to the conclusion that Christ's resurrection was a merely subjective or cultural event.

Watts (2002:143) asserts that the natural and human sciences can illuminate different aspects of the nature of resurrection, but do so most adequately and in the most balanced way when both the natural and the human sciences are taken into account. We should resist choosing between a too objective and a too subjective way of interpreting Christian doctrine. Problems arise when such bias is the basis of a dialogue with the natural sciences and also with psychology. Theology is best located in the intermediary terrain which is neither wholly objective nor wholly subjective. Good theology is best done where the objective and the subjective meet.

\section{METATHEOLOGY}

On a meta-theological level, Watts develops a psychological perspective on the process of doing theology. He highlights the tendency in theology to operate in terms of dichotomies where "... something is said to be this or that" (Watts 2002:151). Dichotomous thinking is not merely a matter of making conceptual distinctions. Distinctions can be helpful and aid clarity of thought. They only become dichotomous if it is assumed that the things being distinguished are completely unrelated to one another, contrast sharply and are incompatible. 


\section{Theology and psychology}

Watts (2002:151) considers three contexts in which such dichotomous thinking arises in theology. The first is epistemological: the too-sharp distinction between self and world, between knower and what is known, and between subjective and objective. The second is the dichotomies in Christian doctrine. For example, in eschatology there can be a dichotomy about whether eternal life is already in the here and now, or is still to come. The third context is the dichotomy between obedience to authority and tradition, in contrast to personal freedom and autonomy in religion. By discussing the three contexts of dichotomous thinking in theology, Watts emphasises the psychological and spiritual importance of avoiding such dichotomies. Faith can only develop in a healthy way when people function in a transitional world between the subjective and the objective. A healthy sense of a relationship with God requires that the sense of separateness from God and union with God should both be given an adequate place. "Finally, to develop their faith, people need to be offered a secure body of tradition and authority, but they need to be left the freedom to rework that tradition for themselves" (Watts 2002:166).

\section{THE DIALOGUE BETWEEN THEOLOGY AND PSYCHOLOGY: A PREDICTION}

Watts states his intention to develop a psychological perspective on the process of doing theology and to encourage others to extend the dialogue between theology and psychology. In this way, his book is open-ended, stating that the discussion is ongoing. He does not claim that everything has been said and done. All possible criticism of his work would therefore probably be answered with: "That is why I invited you to further discussion."

At the beginning of the book Watts mentions four key areas in which dialogue between theology would take place. He discusses three of these areas in his book, but omits the fourth key area of the theological and psychological perspectives on Christian pastoral care. Watts deliberately leaves this specialist area on pastoral care out. In my view, this key area is essential to the discussion, since the other three key areas he discusses require the direction which could be given by Christian pastoral care. However, Watts has accomplished a great deal by initiating such a dialogue between theology and psychology. The dialogue must continue. If this happens, Watts (2002:15) would probably be happy to note that his book "will have done its job." 